\title{
腎術曰耳曰ス
}

\section{スピーカと繊 維}

1.はしがき

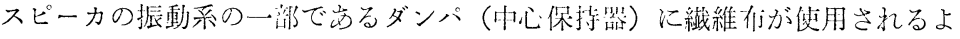
らになってすでに十

数年を数える.

最初は絹に樹脂処 理を施しホットプ レスで任意の型に造 り出した. その後需 要の増大とともに跖 究改良を加光，絹・ 綿・麻などの天然繶 維に熱硬化性の樹脂 を処理し，その目的

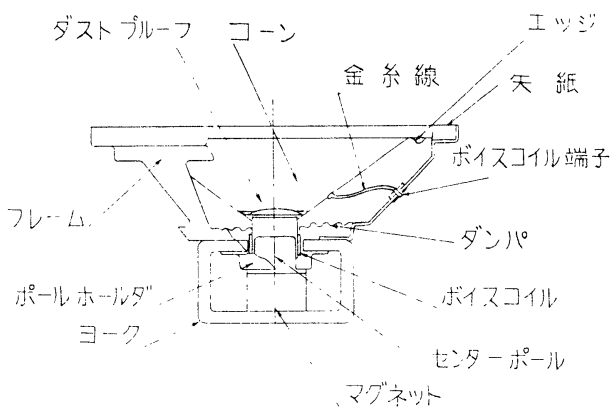

（第1四）スピーカ各部の名称
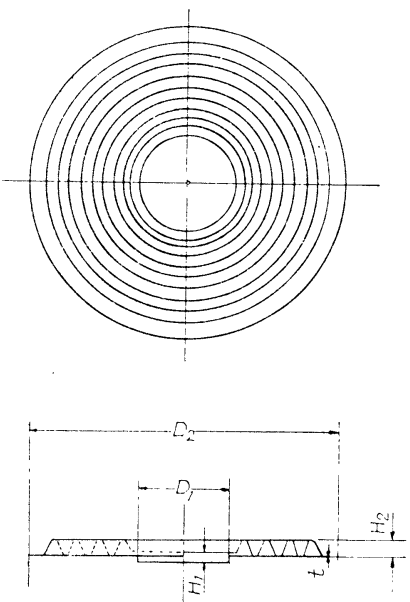

（第 2 図）齐） パ

に供して来たのであるがスピーカの販路の拡大とともに使用条件も歌酷となり，む心整造面からの要求で製造工程で加 熱しても変形しないことなど，性能上拈よび製追上からの要望を満たすためには従来の天然瀻維によるダンパでは困難

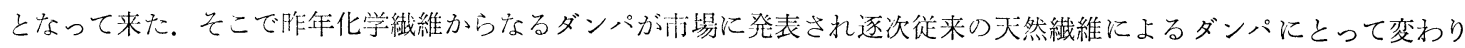
つつ岗る。

\section{2．ダンパの生産量と布の使用量}

スピーカの生産量は第 1 表のごとく月平均約 500 万個が生産されている。 よってダンパも，それを若干上回る数量が 生産されているのである. 絹・綿・化学繊維・不織布・ その他の材料使用分布は第 3 図のごとくである。これに 使用される量（防鷹布を含む）はメ一トル幅で $30000 \mathrm{~m}$ /月とみなされる。

（第1 表） 久ピーカ生座量（通破省調へ）

\begin{tabular}{|c|c|c|c|}
\hline$\cdots$ & 生 産 数 （年間） & 金 & 額（千円） \\
\hline 35年 & 19906749 & & 5883456 \\
\hline $36 " \prime$ & 32933607 & & 8685344 \\
\hline $37 " \prime$ & 36143613 & & 9293674 \\
\hline $38 " \prime$ & 40955215 & & 9172708 \\
\hline $39 \prime \prime$ & 57434.841 & & 10012725 \\
\hline
\end{tabular}

\section{3. ダンパの具備すべき条件}

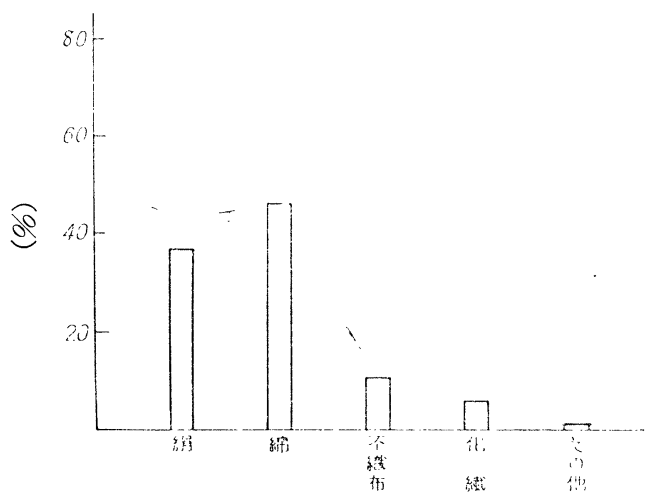

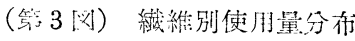

ダンパの具備すべき条件は性能上と製退上に大別されるが大略つぎのよう省るのである.

1. 定㕫北た最低共振周波数 $\left(f_{0}\right)$ を侍与るこ上

2. 応力に対する歪の比例限界が大きく, 残㖉歪が でさるだけ小さいこと

3．温度・湿度などにより変形，变質しないこと

4. 適度の通父量を有する反面じん埃を防ぐこと
5.七ット性が孯いこと

6. 寸法精度が要求さ机た範囲内にあること

7. 作業性, 接着性が良いこと

8. 体格が幂いこと 
もらろん以上のような条件をすべて満足させるダンパ ないのであるができるだけそはれに近づけるべく研究が 続けられ，小口径のスピーカに打将を゙ニロン・テトロ ン・ダンパなどは，ややそれに近いるのである。

\section{4. 化織ダンパの諸特性}

ダンパに使用するビニロン，テトロン布は一般につぎ のよう店タのである。

$$
\begin{aligned}
& \text { ○ 夈 }-20 \mathrm{~d} \times 2 \\
& \text { ○厚 } \\
& \text { ○メッシュー } \\
& \text { ○.08 } 0.14 \mathrm{~mm}
\end{aligned}
$$

a 樹脂の附着量

基有は所定の比重（0.84～0.95）に調整さ れた塗料バスの中を通して一定量着液する。

樹脂はフェノール樹脂. メラミン樹脂, ニリ ア樹脂などの熱硬化性のもので，特にフェノ 一ル樹脂が多く使用される。

b 変形試験

製品を恒温恒湿槽の中で一定条作下で放置 しその変形した度合をみる。

表中の数字は試料 20 枚中の 変形した枚数 である。

c ダンパの㣂位安定性 (ドロップ率)

ダンパの吸湿量の大小はダンパの $f_{0}$ （あるいはコンプライアン

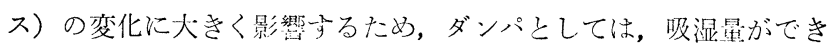
るだけ少ないことが望ましい。

第 3 表は一定条件下で恒温, 恒湿槽で放置 し，その吸湿量を测定したものである。

テトロン・ビニロソは絹に比し大幅に吸湿量は小さく ダンパーの偏位を調ベると第 5 図のと和りである。

ドロップ率とは, 常態時のダンパに一定荷重をかけそ の偏位を読取顕微鏡で読み，その值を $A$ とする。た一 定条件で吸湿させたダンパの偏位を同様にして測定し， これをBとするとつぎの関係をドロップ率といい耐湿性 に闗与る目安とする。

$$
\text { ドロップ率= } \begin{gathered}
B-A \\
A
\end{gathered} \times 100(0)
$$

\begin{tabular}{|c|c|c|c|c|c|c|}
\hline \multirow{2}{*}{$\begin{array}{c}\text { 条件 } \\
\text { 㻉闍 材 } \\
(\mathrm{sec})\end{array}$} & \multicolumn{2}{|c|}{$2^{\circ} \mathrm{C} 60 \% \mathrm{RH}$} & \multicolumn{2}{|c|}{$60^{\circ} \mathrm{C} 60 \% \mathrm{RH}$} & \multicolumn{2}{|c|}{$30^{\circ} \mathrm{C} 90 \% \mathrm{RH}$} \\
\hline & ビニロン & 絹 & ビ & 絹 & ビニロン & 絹 \\
\hline 10 & なL & なし & なし & 20 & $2 \sim 3$ & 10 \\
\hline 20 & "I & 10 & "I & 20 & $2 \sim 3$ & 20 \\
\hline 30 & " & $10 \sim 15$ & "I & 20 & $2 \sim 3$ & 20 \\
\hline 40 & " & $10 \sim 15$ & "l & 20 & $2 \sim 3$ & 20 \\
\hline 50 & "I & $15 \sim 17$ & " & 20 & $4 \sim 5$ & 20 \\
\hline 60 & "I & $15 \sim 17$ & " & 20 & $4 \sim 5$ & 20 \\
\hline
\end{tabular}

\section{5.むす び}

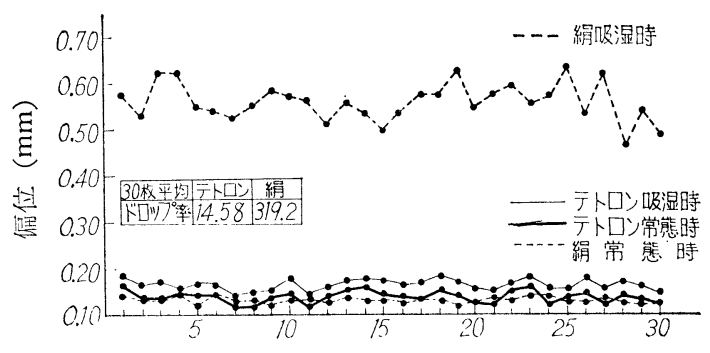

(第 2 表) ダンパの变形比較

（第 3 表）ダンパの吸湿率

\begin{tabular}{c|c|c}
\hline 条 件 & $2{ }^{\circ} \mathrm{C}, 65 \% \mathrm{RH}$ & $20^{\circ} \mathrm{C}, 95 \% \mathrm{RH}$ \\
梦辟 & $20^{2} \mathrm{C}$ & $24 \sim 27$ \\
綿 & 7 & 24 \\
絹 & 11 & 5 \\
ビニロン & 3 & 2.6 \\
テトロン & 1.8 &
\end{tabular}

以上ダンパの概略について紹介したが実際問題としては．多くの制䄪の中で設計され製造されている.

スピーカが励磁型から永久磁石型に変わり，ダンパの形態は今日のごときものになったのであるが，スピーカT業発 展にダンパ技術の貢献は見のがすことはできない.

《(株) 横山霞機製作所的田十四三》 


\section{シリコン フォト ダイオード（太陽電池） の繊維機械への応用}

シリコンの単結晶を主体とする $\mathrm{p} ー \mathrm{n}$ 接合ダイオードによる光起電力効果は，当初太陽エネルギを利用するいわゆる 太陽電池として，開発されてきたが，その後との機能から明らかなよらに，従来のフォトトランジスタや硫化カドミ ウムなどに代わる新しい光電変換素子として注目されるようになった。すなわち，光を媒体とした信号系を制御する方 面に種々利用されることが予想され，すでに電子㖕算機の入力装置をはじめとして，自働制御のあらゆる分野にこの素 子の有用性が立証されつつある。

瀻維機珹の自動化にも，従来は人間の目にたよっていた点をまずこの素子の力を借りることで解決をはかると网㭙 に，エレクトロニクスの導入の媒体ともなることが期待されている.

そこでこの素子の特性と特長を簡単に述べ，現在の繊維機械の応用例を紹介しておく．

\section{1. シリコン フォト ダイオードの特性および特長}

\section{a 出力特 性}

第 1 図は照度をパラメータとした出力電圧対出力電流特性の一例 である. 出力電流は, 照射光の強さと受光面積に比例し, 出力電压 は照射光の強さによって多少变化するが受光面積には無関係である. 第 2 図は負荷をパラメータとした照度対出力電流特性である．負荷 インピーダンスを小さくすればするほど，入射光量の広範囲な変化 に対して出力電流の直線的変化範囲が拡大されることがわかる.

b 分 光 感度特 性

第 3 図は視感度と比較した分光感度特性でこの素子は赤外線にそ の感度の最大值があり, 光源にタングステン ランプを使用すると 变換效率がよくなる，波長の短いところ恋で必要なときは，ブルー セルと称するものを利用すればよい。

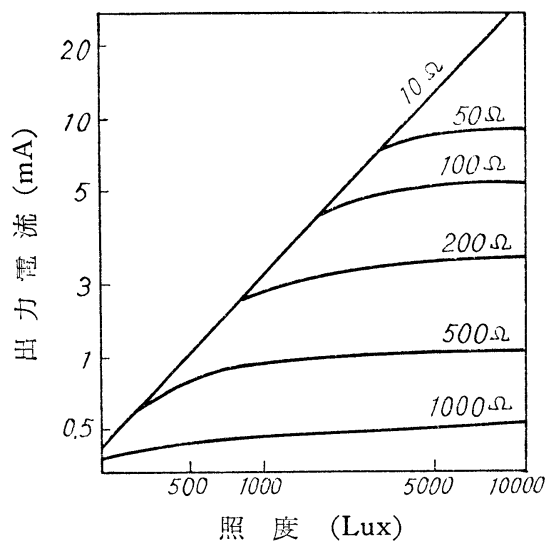

（第2図）真荷をパラメータとした 照度一出力霞流特性

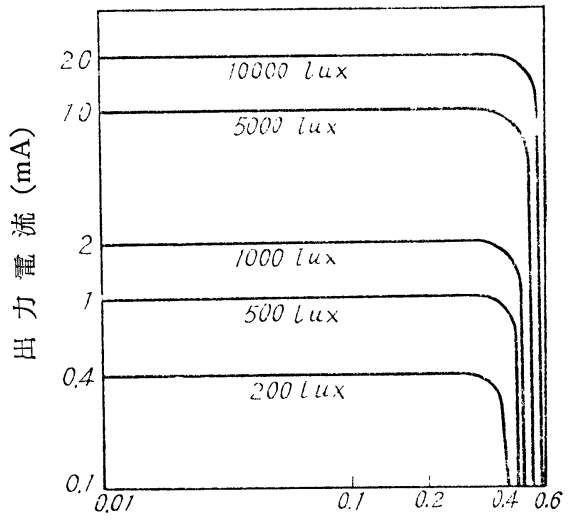

出力電圧 (V)

（第1図）照度をパラメータとした 電流一電壬特性

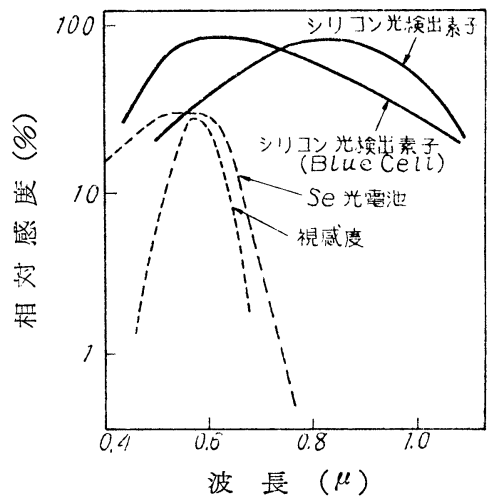

（第 3 図）分光感度特性 
c 温度 特 性

第 4 図は短絡電流と開放電压との温度特性である.シリコンを基体 とした半導体だけに比較的温度による影響は少ない。

$\mathrm{d}$ 特 長

フォトトランジスタや硫化カドミウムと比較して, 顕著な特長を 以下に列挙する。

（1）光起電力効果を利用するため, 素子そのものに対するバイア ス電源を必要としない

（2）負荷を適当に選ぶことによって，相当広範囲な照度変化に対 して直線的な出力を得ることができる

（3）動作原理からみて S N比がきわめてよく，フォトトランジ スタと比較にならないほど雑音が少ない

（4）多数個を組にして使用するとき, 同一単結晶からその組を製 作できるので，個々の素子の特性上のばらつきが少ない

（5）各素子のばらつきが少ないことと指向性が鋭くないので, フォトトランジスタのように光軸の調整を必要と せず，制御装置などの取りつけ調整が簡単で経済的である

（6）波長感度分布が広く，特に赤から近赤外の領域で最大感度を有するため，タングステン ランプを光源として 利用するのに適している. 光源に対して分光感度特性を多少変化させることもできる.

（7）温度特性が比較的よく約 $150^{\circ} \mathrm{C}$ まで利用できる

（8）構造的に簡単であるため堅牢で寿命が長く信頼性がある

\section{2. 織維機械への応用}

光を媒体とした繊維機械の自動化は，最近フォトトランジスタなどを利用して，著しく開発が進展してきた。 しか しフォトトランジスタは温度変化に対して信頼性が得られないばかりではなく, 光軸の調整が困難で多数の素子を並べ て使用するときに実用性がそしいきらいがある。この欠点を完全にカバーしたのがこのシリコンフォトダイオードで ある。

これまでにこの素子を用いて実用化されているか，または実用化されつつあるものの一部を拾ってみると，つぎのよ らなものがある

（1）トリコット䋹機自働停止装置

(2) スラブキャッチャ

(3) フィーラ

(4) 毛羽発見機

(5) 検反機

これらのものは，すべて従来は人間の眼にたよっていたものを，眼の代わりにこの素子をおきかえたものであること がわかるが，このほかにプログラマとして，電子計算機との結合を実現させようと試みたものに紋織機用紋紙自動穿孔 装置などがある。

ここでは,トリコット編機自働停止装置について，このシリコンフォトダイオードが実際にどのように利用されて いるかを簡単に説明しておく.

この装置を編機に取りつけ動作中の状態が（写真 1) である.たて系が切れ，編まれたトリコット生地の進行方向に きずが生ずると，生地の上面を常に走行している検知へッドがこのきずを検知して編機自身の停止を指令するようにな 


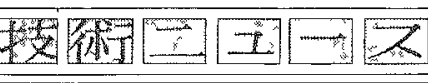

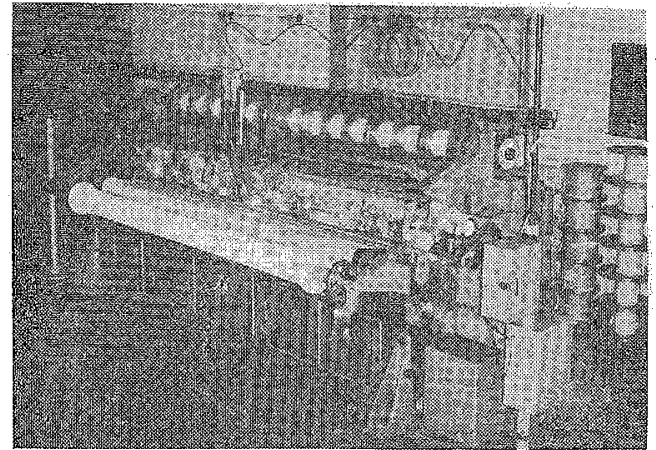

(军真 1) 下y

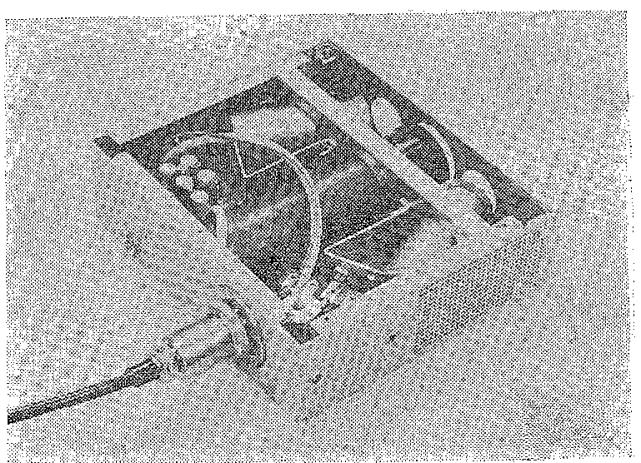

(军悬 2) 检出へッド

っている.

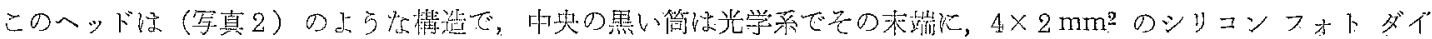
オードがる。

この素子は，レンズ系の両側の電球の照䐓炕よるトリニットの表面からの乱反射光を常に受け，きずのために一瞬反

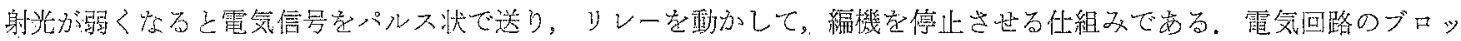

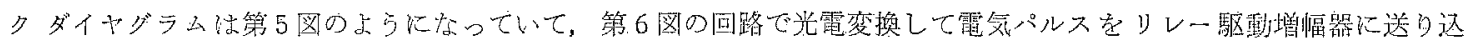
んでいる。

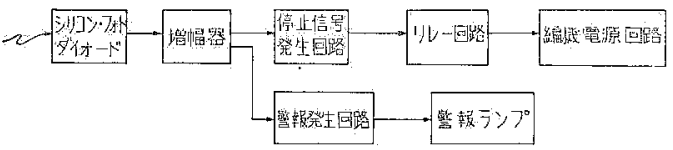

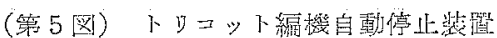
ブロッタダイヤグラム

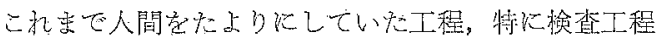

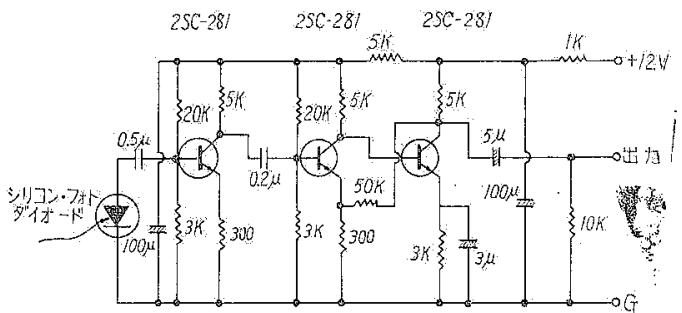

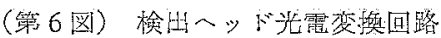

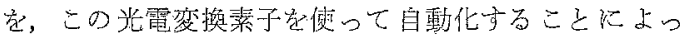

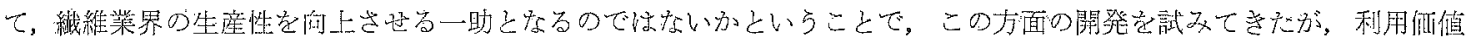

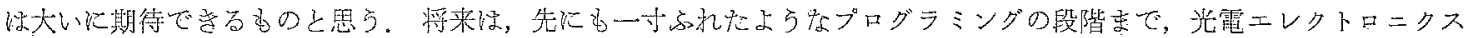
を策用化できるよう努力したい。

優》

\section{染色と仕上を 1 段階で}

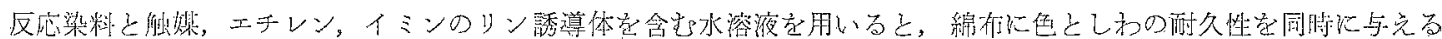

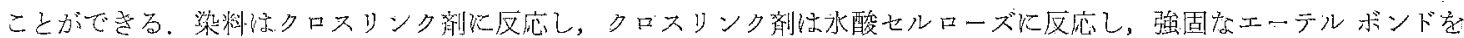

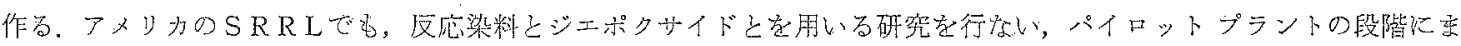

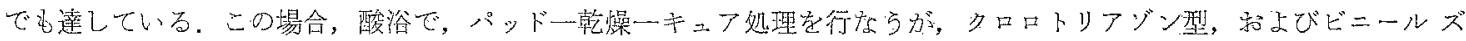

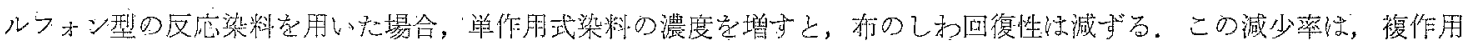
型染料悹用い天場合上り大㤩い。

(Text. Ind., 109 (1964-12) より) 


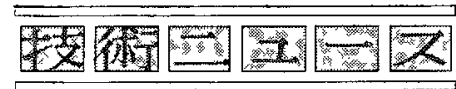

\section{たて編みにおける}

\section{品 質 管 理}

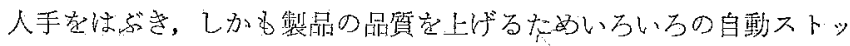

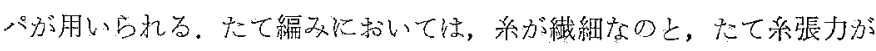
小さいため，ドラッパ式でなく，編地傷がでさてから，反射光睤の変 化学㛟出して停める事のが一部に採用されつつある。

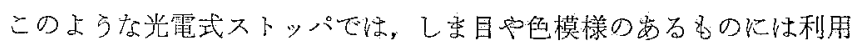

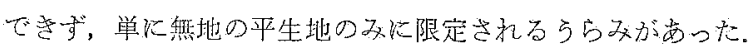

今回アメリカでテストされた A S M - 7 型走查装置は, 従来之原理を

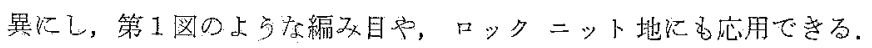

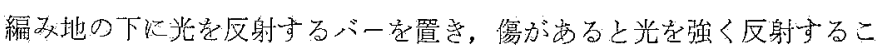

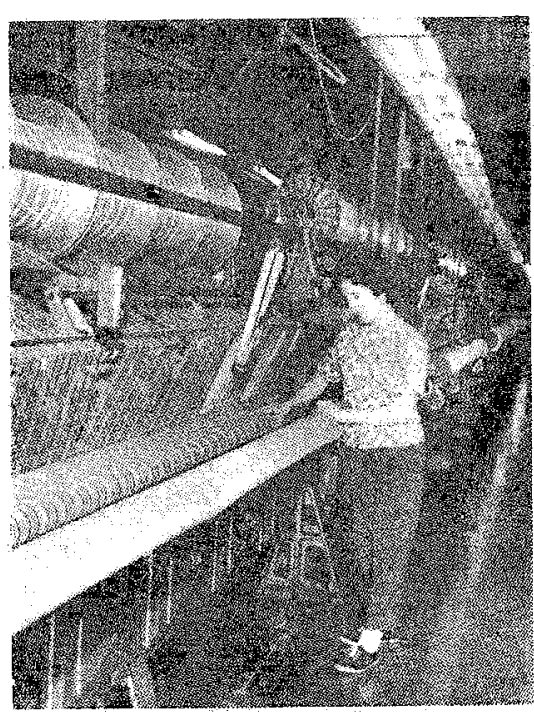

(第 1 园)

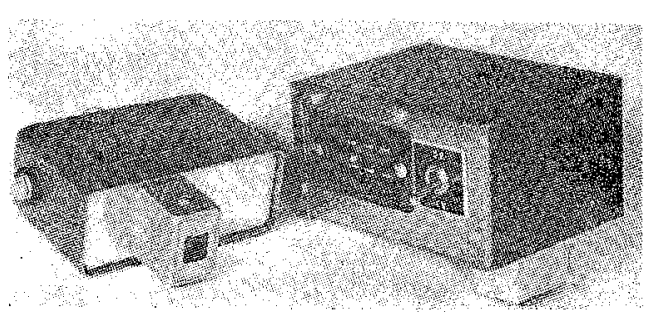

(第 2 区)

とを利用したものである。いま亲で慯があると反射光が へったが，生地よりの反射光量自身は小さいので，反射光 量のへりも小さい, 新型では, 布の反射に比べ非常绐い 反射光量が得られ，少しぐらいの外部の明るさの大小飞は 影響さ机ない。第 2 図位新しい走查用へッド（左）と，プ リアンプ(右) 杂す

(Text. Merc. Intern., 151, 3921，(1965-3-5) より)

\section{$\therefore$ 海外織維技術文献集：。【9月号内容紹介】}

本誌は海外の瀻維関係の雑誌文献など䄪 100 種のらちより，興味ある諭文每号訳出揭

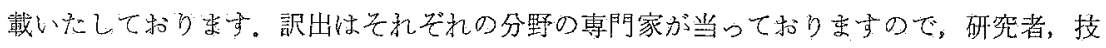
術者の方々の恰好の資料となることと信じすす。

会員の皆様の海外資料研究部会への入会を战すすかいたします。

- 新しい合成樹脂イオノマ

- 合成繊維ベッケ線属折率の意義

○ポりビニルアルコールルよる表面サイズの新しいう法

織物の幾何学一力学的構造の一般モデル

・新しいフォ一ムラミネート法

- 羊毛仕上げ㙨械の傾同

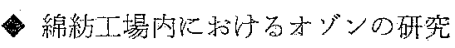

Kunstoffe, (1965-5)

Text. Res. J., (1965-3)

Tappi, (1960-11)

J. Text. Inst., (1964-11)

Melliand Textilber., (1964-12)

Text. Ind., (1964-11)

Text. Res. J., (1965-2)

(海外凟料研究部会) 